\title{
ASSESSMENT OF NUTRITIONAL STATUS OF URBAN SCHOOL CHILDREN OF GHAZIBAD CITY AGED 3 -14 YEARS: A PILOT STUDY
}

\author{
Rinku Garg', Ravi Kant Sehgal2, Sharmila Anand ${ }^{3}$, Sreetama Chatterjee 4 \\ ${ }_{1}^{1}$ Associate Professor, Department of Physiology, Santosh Medical College and Hospital, Ghaziabad. \\ ${ }^{2}$ Associate Professor, Department of Community Medicine, Santosh Medical College and Hospital, Ghaziabad. \\ ${ }^{3}$ Assistant Professor, Department of Pharmacology, Santosh Medical College and Hospital, Ghaziabad. \\ ${ }^{4}$ Assistant Professor, Department of Prosthodontics, Santosh Medical College and Hospital, Ghaziabad.
}

ABSTRACT: BACKGROUND: Malnutrition continues to be a primary cause of ill-health and morbidity in children.

AIMS AND OBJECTIVES: Thus the aim of the present study was designed to assess the nutritional status of school children of Ghaziabad aged 3-16 years.

MATERIAL AND METHODS: A cross-sectional study was carried out amongst 558 school children aged 3-16 years in Ghaziabad city. Anthropometric variables age, height, weight and body mass index were recorded. Based on these parameters prevalence of underweight and stunting was calculated in comparison with NCHS standards

RESULTS: showed that out of total 558 children, 292(52.3\%) were underweight (180 boys and 112 girls) and 59(10.5\%) were stunted ( 39 boys and 20 girls).

CONCLUSION: There is specific need to look into the nutritional requirements of children by the Government sector in conjuction with education department.

KEYWORDS: School Health, Nutritional Status, Underweight, Stunting.

HOW TO CITE THIS ARTICLE: Rinku Garg, Ravi Kant Sehgal, Sharmila Anand, Sreetama Chatterjee. "Assessment of Nutritional Status of Urban School Children of Ghazibad City Aged 3 -14 Years: A Pilot Study". Journal of Evolution of Medical and Dental Sciences 2015; Vol. 4, Issue 88, November 02; Page: 15321-15324, DOI: 10.14260/jemds/2015/2178.

INTRODUCTION: With rapid growth and development in the country, there is a growing concern over the aspect of child health. In order to combat the health problems of school children, Government of India has launched School Health Program under National Rural Health Mission (NRHM) which is currently being implemented in 33 states/UTs. This program comprises of screening of health status of the students which includes assessment of anaemia, nutritional status, visual acuity, hearing problems, dental check-up and the common skin diseases. The program also includes micronutrient supplementation and treatment of minor ailments along-with provision of immunization services and health education of the children. The program is run in conjunction with Ministry of Human Resource and Development. ${ }^{1}$

Nutritional status is the condition of health of an individual as influenced by nutrient intake and utilization in the body. Malnutrition is a major public health problem and accounts for about half of all child deaths worldwide. About 150 million children in developing countries are still malnourished and more than half of underweight children live in South East Asia Region (SEAR). The high levels of under nutrition in children in South Asia pose a major challenge for child survival and development. ${ }^{2}$

Financial or Other, Competing Interest: None

Submission 07-10-2015, Peer Review 08-10-2015,

Acceptance 20-10-2015, Published 31-10-2015.

Corresponding Author:

Dr. Rinku Garg,

H. No. $M P-1 / 204$

Eledeco Aamntran, Sec-119, Noida.

E-mail: rgrinkigarg6@gmail.com

DOI: $10.14260 /$ jemds/2015/2178.
Studies have shown that the prevalence of underweight children is highest in the world. ${ }^{3}$ Malnutrition affects the physical and cognitive development that slows economic growth and aggravates poverty. 4

School plays an important role in all round development of the children which includes the physical, mental as well as emotional aspects. ${ }^{5-6}$ The school age period is nutritionally significant because this is the prime time to build up body stores of nutrients which will be required subsequently for the rapid growth during adolescence. Protein/calorie deficient diet during childhood results in children being underweight and having wasting and lowered resistance to infection besides stunted growth and impaired cognitive development and learning.7,8 School provides the most efficient and effective medium to reach large portion of the children of school age group. ${ }^{9}$

Under-nutrition in children, which can manifest itself in many ways, is most commonly assessed through the measurement of weight and height. A child can be too short for his or her age (stunted), can have low weight for his or her height (wasted), or can have low weight for his or her age (underweight). A child who is underweight can also be stunted or wasted or both. 10

Although Govt. of India is running the Mid-Day Meal (MDM) school program, not much data is available on the nutritional status of school children of Ghaziabad City. Therefore there is a need to find out the prevalence of malnutrition and undernutrition among the school children in the city.

A survey has therefore been planned to assess the nutritional status of school going children, the building blocks of state and country.

The present study was carried out in Ghaziabad with following objectives: 
1. To assess the nutritional status of school going children of 3 to 16 years age group in Ghaziabad City.

2. To find out the prevalence of underweight and stunted children amongst them.

MATERIAL \& METHODS: The present study was a descriptive population based cross-sectional study, conducted by Santosh Medical College and Hospital, Ghaziabad. Ethical approval was taken from the research committee of the Institution before starting the study.

Study was conducted in seven schools, which included both Government and private schools, of Ghaziabad, during the period Nov 2014 to Feb 2015.The schools were selected using simple random sampling technique.

Five hundred fifty eight children of both sexes, in the age group of 3-16 years were randomly selected for the study. The administrative staff in the selected School was contacted and the objectives of the study explained. A letter was sent to every parent explaining the procedure and seeking permission to evaluate the child.

Inclusion Criteria: School going children in the age group of 3-16 years present at the day of the study.

Exclusion Criteria: Students those who were absent at the day of the study and could not be contacted by the teacher.

Anthropometric Parameters: Age was taken as completed years on the school records. Height was measured using a standard stadiometer with the subject standing in erect posture with the heel and back against the wall without footwear. The readings were taken to the nearest $0.1 \mathrm{~cm}$. Weight was recorded in Kgs using a calibrated portable weighing machine (Avery), with a capacity of $120 \mathrm{~kg}$ and a sensitivity of $0.05 \mathrm{~kg}$. The students were weighted without wearing shoes and with minimal clothes bearing equal weight on both feet.

The mean weight and height for the age and sex of the children were compared with the mean height and weight for the age as per ICMR Standards.The nutritional status of the children was assessed by assessing their weight for age (wasting) and height for age (stunting) as per waterlow classification. ${ }^{11-13}$

Statistical Analysis. Results were analysed by ANOVA with SPSS version 17.0.

DISCUSSION: The present study included five hundred fifty eight students out of which 347were boys (62.19\%) and 211 were girls (37.81\%). (Table 1) Table 2 shows that there is increase in height of boys and girls with increase in age.

The total increase in in height during the period of 3-16 years was $72.92 \mathrm{cms}$ in case of boys and 72.21 in case of girls. Maximum gain in height was seen in 5-6 years age group in case of boys and 6-7 years in case of girls. When compared with NCHS standards, the mean heights of both the boys and girls in all age-groups were lower. Similar findings were shown by various authors. ${ }^{14}$

Table 3 shows that mean weight of the boys increased with age except between the age of 8 and 9 years, where a decrease in mean weight of the boys was noted as compared to girls mean weight which increased consistently with age. Mean weight of boys was more in all age groups except 6, 7, 9 $\& 10$ years where the girls were heavier than boys. But when compared with NCHS standards, mean weight of both boys and girls were less in age groups. J Semwal has shown the similar fidings in their study. ${ }^{15-16}$ The total gain in weight from 3 to 16 years age was $35.1 \mathrm{kgs}$ in boys and $34.2 \mathrm{kgs}$ in girls.

Table 4 shows the coefficient of correlation between height and weight of all ages in both the boys and girls. Maximum correlation was found at the age of $4 \& 6$ years (0.81) in case of boys and at the age of 7 years (0.86) in girls. Coefficient of correlation was statistically significant at all ages for both the genders except at age of three years in boys and five, thirteen and fifteen in case of girls. Similar findings were reported by Mullick and Khan. ${ }^{15,16}$ Table 5 shows the prevalence of undernutrition and stunting in children. Out of total 558 children, 292(52.3\%) were underweight (180 boys and 112 girls) and 59(10.5\%) were stunted ( 39 boys and 20 girls). Prevalance of underweight in our study is similar to various authors. ${ }^{17-19}$ However, prevalence of stunting in our study was less as compared to Handa et al. ${ }^{20}$ and Mukherjee et al. ${ }^{21}$

CONCLUSIONS: There is specific need to look into the nutritional requirements of children by the Government sector in conjuction with education department. Regular clinical examination of all children should be included in school curriculum so that morbid diseases caused by poor nutritional status can be prevented. For this health education to the school teachers as well as parents of the children should be done.

ACKNOWLEDGMENT: We are thankful to all the students, school staff and and staff of Santosh Hospital for their contribution in the completion of the project.

\section{REFERENCES:}

1. Annual Report 2010-11.Department of Health and Family Welfare, Ministry of Health and Family Welfare, Government of India. Page No.71 [Cited 2012 Nov12]; Available. from:URL:http://mohfw.nic.in/showfile.php?li=1091.

2. UNICEF (2004), State of world's Children, 2004.

3. National nutrition monitoring Bureau report on diet and nutritional status of adolescent, National Institute of Nutrition, India, 2002.

4. Mason J B (2003) Atleast one third of poor countries burden is due to malnutrition: diseses control priorities project: working paper no.1, March 2003.

5. WHO Report.Life in the $21^{\text {st }}$ century-A vision for all. Geneva: WHO; 1998,93.

6. UNICEF. The State of The World's Children (online).1999[Cited 2012 Nov 12];Available from :URL:http://www.unicef.org/sowc99/sowc99a.pdf

7. Kumari $S$ and Jain R.Assessment of school children from rural Bihar.Ind J Nutr Dietet 2005. 42:326-334.

8. Gowri AR and Sangunam H J.Assessment of mental and motor abilities of school going children with anaemia.Ind J of Nutr. Dietet 2005. 42:99-105.

9. WHO, Information series on school health,document 13,Malaria prevention and control: An important responsibility of a health promoting school,2007.

10. Ghai OP, Gupta P, Paul VK. Ghai essential paediatrics, adolescent health and development. Pediatrics 2006;6:66

11. Whyte HM: Behind the adipose curtain. Am J Cardiol 1965;15:66-80. 
12. Barlow SE, Dietz WH. Obesity evaluation and treatment: Expert Committee recommendations. The Maternal and Child Health Bureau, Health Resources and Services Administration and the department of Health and Human Services. Pediatrics 1998;102:e29.Available from.

URL:http://pediatrics.aappublications.org/cgi/reprint /102/3/e29. Accessed January 12,2008. CrossRef.

13. Department of Health and Human Services. Centers for Disease Control and Prevention, USA.CDC growth charts for the United States [database on the internet]. Available at http://www.cdc.gov/nchs/data/nhanes/growth charts/zscore/bmiagerev.xls. Accessed January 12,2008 .

14. ICMR (1989): Growth and physical development of Indian infants and children. Technical Report Series No.18.

15. Mullick H. Assessment of health status of urban primary school children of Jhansi (Uttar Pradesh). Thesis submitted for M.D. in community Medicine.1991: Bundelkhand University, Jhansi.
16. Khalil S and Khan Z. Physical growth and nutritional status of rural school going children (6-14 years) of Aligarh. Ind J Prev Soc Med 2004.35 (3\&4):90-98.

17. Anathakrishnan S, Pant SP and Nalini P.A comprehensive study of morbidity in school age children. Ind Paediatr 2001; 38: 1009-1017.

18. Kokiwar PR and Sai Prasad GS. A study of nutritional status of children in a village of Andhra Pradesh Souvenir; 32nd Annual National Conference of IAPSM and $12^{\text {th }}$ Annual Conference of MCIAPSM;2005:65.

19. Damodharan G, Ravichandran C, Vijaykumar V, Senduttuvan M. Nutritional status and pattern of illness in Chennai corporation primary school children. Ooty Pedicon 2005-Conference Abstracts. Pediatric Oncall [serial online] 2005[cited 2010 March 8];2. Available from:

http://www.pediatriconcall.com/fordoctor/Conference_a bstracts/nutrition.asp.

20. Handa R, Ahmad F, Kesari KK, Asad R. Assessment of nutritional status of 7-10 years school going children of Allahabad district: A Review. Middle-East Journal of Scientific Research.2008; 3(3):109-115.

21. Maj Mukherjee R, Lt Col Chaturvedi S, Col Bhalwar R. Determinants of nutritional status of school children. MJAFI.2008; 64: 227-231.

RESULTS :

\begin{tabular}{|c|c|c|c|c|c|c|c|}
\hline \multirow{3}{*}{$\begin{array}{l}\text { Age of sex } \\
\text { in years }\end{array}$} & \multicolumn{4}{|c|}{ Sex } & \multicolumn{2}{|c|}{ Total } & \multirow{3}{*}{$\mathbf{r}$} \\
\hline & \multicolumn{2}{|c|}{ Boys } & \multicolumn{2}{|c|}{ Girls } & \multirow{2}{*}{ No } & \multirow{2}{*}{$\%$} & \\
\hline & No & $\%$ & No & $\%$ & & & \\
\hline 3 & 15 & 0.59 & 4 & 1.90 & 19 & 0.82 & \multirow{15}{*}{0.87} \\
\hline 4 & 11 & 1.59 & 7 & 3.32 & 18 & 1.89 & \\
\hline 5 & 18 & 0.79 & 2 & 0.95 & 20 & 0.82 & \\
\hline 6 & 10 & 0.99 & 14 & 6.64 & 24 & 1.97 & \\
\hline 7 & 21 & 2.08 & 18 & 8.53 & 39 & 3.20 & \\
\hline 8 & 12 & 1.19 & 11 & 5.21 & 23 & 1.89 & \\
\hline 9 & 20 & 1.98 & 11 & 5.21 & 31 & 2.54 & \\
\hline 10 & 35 & 3.47 & 22 & 10.43 & 57 & 4.67 & \\
\hline 11 & 56 & 5.55 & 28 & 13.27 & 84 & 6.89 & \\
\hline 12 & 76 & 7.53 & 11 & 5.21 & 87 & 7.13 & \\
\hline 13 & 10 & 10.11 & 14 & 6.64 & 24 & 9.51 & \\
\hline 14 & 18 & 18.73 & 11 & 5.21 & 29 & 16.39 & \\
\hline 15 & 19 & $18+.83$ & 17 & 8.06 & 36 & 16.97 & \\
\hline 16 & 26 & 26.56 & 41 & 19.43 & 67 & 25.33 & \\
\hline Total & 347 & 100.00 & 211 & 100.00 & 558 & 100.00 & \\
\hline \multicolumn{8}{|c|}{$\begin{array}{l}\text { Table 1: Age \& Sex - wise distribution of study subjects } \\
\text { and correlation coefficient b/w age and height }\end{array}$} \\
\hline
\end{tabular}

\begin{tabular}{|c|c|c|c|c|c|c|c|c|}
\hline \multirow[b]{3}{*}{$\begin{array}{c}\text { Age } \\
\text { (Years) }\end{array}$} & \multicolumn{8}{|c|}{ Sex } \\
\hline & \multicolumn{3}{|c|}{ Boys } & & \multicolumn{3}{|c|}{ Girls } & \multirow[b]{2}{*}{$\begin{array}{c}\% \text { of } \\
\text { Reference }\end{array}$} \\
\hline & No & Mean \pm SD & $\begin{array}{c}\text { References } \\
\text { value } \\
\left(50^{\text {th }}\right. \\
\text { percen } \pm \text { tile } \\
\text { of } N C H S)\end{array}$ & $\begin{array}{c}\% \text { of } \\
\text { Reference }\end{array}$ & No & Mean \pm SD & $\begin{array}{c}\text { References } \\
\text { value } \\
\text { (50th } \\
\text { percentile } \\
\text { of NCHS) }\end{array}$ & \\
\hline 3 & 15 & $95.50 \pm 2.34$ & 98.2 & 97.25 & 4 & $87.25 \pm 5.43$ & 98.1 & 88.94 \\
\hline 4 & 11 & $99.68 \pm 7.26$ & 106.8 & 93.33 & 7 & $97.14 \pm 6.28$ & 105.2 & 92.34 \\
\hline 5 & 18 & $102.12 \pm 5.24$ & 114.6 & 89.11 & 2 & $104.5 \pm 4.94$ & 111.7 & 93.55 \\
\hline 6 & 10 & $110.90 \pm 6.15$ & 120.8 & 91.80 & 14 & $112.21 \pm 6.82$ & 118.2 & 94.93 \\
\hline 7 & 21 & $118.66 \pm 8.77$ & 125.2 & 94.78 & 18 & $119.72 \pm 9.35$ & 125.6 & 95.32 \\
\hline 8 & 12 & $124.66 \pm 9.08$ & 130.3 & 95.67 & 11 & $124.18 \pm 8.48$ & 130.5 & 95.16 \\
\hline 9 & 20 & $129.65 \pm 7.87$ & 137.1 & 94.57 & 11 & $130.09 \pm 9.84$ & 138.3 & 94.06 \\
\hline 10 & 35 & $136.71 \pm 9.90$ & 141.5 & 96.61 & 22 & $136.72 \pm 9.13$ & 143.7 & 95.14 \\
\hline 11 & 56 & $140.51 \pm 8.70$ & 149.4 & 94.05 & 28 & $142.57 \pm 13.53$ & 151.4 & 94.17 \\
\hline 12 & 76 & $146.7 \pm 11.44$ & 153.9 & 95.32 & 11 & $149.09 \pm 6.20$ & 156.7 & 95.14 \\
\hline
\end{tabular}




\begin{tabular}{|c|c|c|c|c|c|c|c|c|}
\hline 13 & 10 & $153.74 \pm 9.52$ & 162.2 & 94.78 & 14 & $153.42 \pm 5.07$ & 151.7 & 101.13 \\
\hline 14 & 18 & $161.22 \pm 9.15$ & 169.0 & 95.39 & 11 & $143.63 \pm 12.52$ & 161.0 & 89.21 \\
\hline 15 & 19 & $165.05 \pm 8.39$ & 174.8 & 94.42 & 17 & $157.94 \pm 7.10$ & 162.0 & 97.49 \\
\hline 16 & 26 & $168.42 \pm 8.63$ & 176.0 & 95.69 & 14 & $159.46 \pm 7.74$ & 162.8 & 97.94 \\
\hline Total & $\mathbf{3 4 7}$ & \multicolumn{7}{|c|}{ Table 2: Distribution According to Height of Children (Mean \pm SD) } \\
\hline
\end{tabular}

\begin{tabular}{|c|c|c|c|c|c|c|c|c|}
\hline \multirow[b]{3}{*}{$\begin{array}{c}\text { Age } \\
\text { (Years) }\end{array}$} & \multicolumn{7}{|c|}{ Sex } & \multirow[b]{3}{*}{$\begin{array}{c}\% \text { of } \\
\text { Reference }\end{array}$} \\
\hline & \multicolumn{4}{|c|}{ Boys } & \multicolumn{3}{|c|}{ Girls } & \\
\hline & No & Mean \pm SD & $\begin{array}{c}\text { References } \\
\text { value } \\
\left(50^{\text {th }}\right. \\
\text { percentile } \\
\text { of NCHS) }\end{array}$ & $\begin{array}{c}\% \text { of } \\
\text { Reference }\end{array}$ & No & Mean \pm SD & $\begin{array}{c}\text { References } \\
\text { value } \\
\text { (50th } \\
\text { percentile } \\
\text { of NCHS) }\end{array}$ & \\
\hline 3 & 15 & $15.00 \pm 0.63$ & 15.3 & 98.04 & 4 & $12.5 \pm 0.57$ & 16.8 & 71.43 \\
\hline 4 & 11 & $15.18 \pm 2.66$ & 18.1 & 105.4 & 7 & $14.28 \pm 1.11$ & 19.4 & 73.06 \\
\hline 5 & 18 & $15.75 \pm 1.16$ & 21.0 & 75.0 & 2 & $15.5 \pm 0.7$ & 22.1 & 70.13 \\
\hline 6 & 10 & $17.30 \pm 3.23$ & 23.7 & 72.99 & 14 & $17.78 \pm 2.88$ & 25.3 & 70.27 \\
\hline 7 & 21 & $21.00 \pm 5.85$ & 25.6 & 82.03 & 18 & $21.72 \pm 5.02$ & 29.7 & 73.13 \\
\hline 8 & 12 & $24.08 \pm 7.53$ & 29.0 & 83.03 & 11 & $23.45 \pm 3.85$ & 33.9 & 69.7 \\
\hline 9 & 20 & $23.80 \pm 4.31$ & 32.3 & 73.68 & 11 & $25.45 \pm 6.99$ & 42.0 & 60.59 \\
\hline 10 & 35 & $26.28 \pm 4.55$ & 37.3 & 70.45 & 22 & $28.31 \pm 5.80$ & 49.0 & 57.78 \\
\hline 11 & 56 & $30.17 \pm 6.84$ & 44.2 & 68.25 & 28 & $31.32 \pm 9.47$ & 56.7 & 55.24 \\
\hline 12 & 76 & $32.72 \pm 7.78$ & 46.9 & 69.76 & 11 & $37.81 \pm 7.20$ & 59.7 & 63.33 \\
\hline 13 & 10 & $38.13 \pm 8.16$ & 55.6 & 68.58 & 14 & $47.78 \pm 8.83$ & 63.4 & 75.36 \\
\hline 14 & 18 & $45.12 \pm 9.51$ & 59.8 & 75.45 & 11 & $38.00 \pm 8.93$ & 64.8 & 58.64 \\
\hline 15 & 19 & $46.68 \pm 8.43$ & 66.3 & 70.40 & 17 & $44.11 \pm 7.67$ & 67.6 & 65.25 \\
\hline 16 & 26 & $50.10 \pm 8.94$ & 70.3 & 71.27 & 41 & $46.70 \pm 11.94$ & 67.0 & 69.70 \\
\hline Total & 347 & & & & 211 & & & \\
\hline & & $T$ & - & 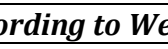 & t of & Iren (Me & & \\
\hline
\end{tabular}

\begin{tabular}{|c|c|c|c|c|c|c|}
\hline \multirow{3}{*}{$\begin{array}{c}\text { Age } \\
\text { (Years) }\end{array}$} & \multicolumn{6}{|c|}{ Sex } \\
\hline & \multicolumn{3}{|c|}{ Boys } & \multicolumn{3}{|c|}{ Girls } \\
\hline & No & $\begin{array}{c}\text { Correlation } \\
\text { coefficient }\end{array}$ & $P$ value & No & $\begin{array}{c}\text { Correlation } \\
\text { coefficient }\end{array}$ & $P$ value \\
\hline 3 & 15 & -0.27 & 0.6 & 4 & 0.58 & 0.42 \\
\hline 4 & 11 & 0.81 & 0.00 & 7 & 0.70 & 0.075 \\
\hline 5 & 18 & 0.80 & 0.017 & 2 & -1.00 & - \\
\hline 6 & 10 & 0.81 & 0.004 & 14 & 0.79 & 0.001 \\
\hline 7 & 21 & 0.53 & 0.013 & 18 & 0.86 & 0.00 \\
\hline 8 & 12 & 0.69 & 0.012 & 11 & 0.68 & 0.021 \\
\hline 9 & 20 & 0.56 & 0.009 & 11 & 0.58 & 0.059 \\
\hline 10 & 35 & 0.71 & 0.00 & 22 & 0.44 & 0.038 \\
\hline 11 & 56 & 0.55 & 0.00 & 28 & 0.76 & 0.00 \\
\hline 12 & 76 & 0.77 & 0.00 & 11 & 0.73 & 0.009 \\
\hline 13 & 10 & 0.69 & 0.00 & 14 & 0.36 & 0.19 \\
\hline 14 & 18 & 0.58 & 0.00 & 11 & 0.85 & 0.001 \\
\hline 15 & 19 & 0.60 & 0.00 & 17 & 0.21 & 0.39 \\
\hline 16 & 26 & 0.36 & 0.00 & 41 & 0.31 & 0.043 \\
\hline Total & 347 & & & 211 & & \\
\hline & & betw & . & on & $(r)$ & \\
\hline
\end{tabular}

\begin{tabular}{|c|c|c|}
\hline Gender & $\begin{array}{c}\text { Underweight (Weight }<\mathbf{8 0} \% \text { of 50 } \\
\text { percentile of NCHS Standard) } \\
\text { No (\%) }\end{array}$ & $\begin{array}{c}\text { Stunting (Height }<90 \% \text { of 50th } \\
\text { percentile of NCHS Standard) } \\
\text { No (\%) }\end{array}$ \\
\hline Boys & $180(51.9)$ & $39(11.2)$ \\
\hline Girls & $112(53.1)$ & $20(9.5)$ \\
\hline \multicolumn{2}{|c|}{ Table 5: Prevalance of Underweight and stunting among children } \\
\hline
\end{tabular}

